\title{
Chemical control of colossal magnetoresistance in manganites
}

\author{
Chih-Hung Shen ${ }^{a}$, Ru-Shi Liu ${ }^{\mathrm{a}, *}$, Ravi Gundakaram ${ }^{\mathrm{a}}$, Shu-Fen Hu ${ }^{\mathrm{b}}$, \\ Jauyn Grace Lin ${ }^{\mathrm{c}}$, Chao-Yuan Huang ${ }^{\mathrm{c}, \mathrm{d}, \mathrm{e}}$, Chien-Min Wang ${ }^{\mathrm{f}}$ \\ a Department of Chemistry, National Taiwan University, No. 1 Roosevelt Road, Section 4, Taipei 106, Taiwan \\ b National Nano Device Laboratories, Hsinchu, Taiwan \\ ${ }^{\mathrm{c}}$ Center for Condensed Matter Sciences, National Taiwan University, Taipei, Taiwan \\ ${ }^{\mathrm{d}}$ Department of Physics, National Taiwan University, Taipei, Taiwan \\ e Department of Electrical Engineering, National Taiwan University, Taipei, Taiwan \\ ${ }^{\mathrm{f}}$ SYNergy ScienTech Corp., Hsinchu, Taiwan
}

\begin{abstract}
The evolution of the structural, electrical and magnetic properties with the isovalent chemical substitution of $\mathrm{Ca}^{2+}$ into the $\mathrm{Sr}^{2+}$ sites in the new series of two-dimensional $\mathrm{La}_{1.2}\left(\mathrm{Sr}_{1.8-x} \mathrm{Ca}_{x}\right) \mathrm{Mn}_{2} \mathrm{O}_{7}$ samples $(0 \leq x \leq 0.8)$ and three-dimensional $\mathrm{La}_{0.6}\left(\mathrm{Sr}_{0.4-x} \mathrm{Ca}_{x}\right) \mathrm{MnO}_{3} \mathrm{samples}$ $(0 \leq x \leq 0.4)$ has been investigated. The compositional dependence of the structural variation has been found in $\mathrm{La}_{0.6}\left(\mathrm{Sr}_{0.4-x} \mathrm{Ca}_{x}\right) \mathrm{MnO}_{3}$. The Curie temperatures $\left(T_{\mathrm{C}}\right)$ decreased from 135 to $102 \mathrm{~K}$ and 370 to $270 \mathrm{~K}$ for $x=0-0.4$ in $\mathrm{La}_{1.2}\left(\mathrm{Sr}_{1.8-x} \mathrm{Ca}_{x}\right) \mathrm{Mn}_{2} \mathrm{O}_{7}$ and $\mathrm{La}_{0.6}\left(\mathrm{Sr}_{0.4-x} \mathrm{Ca}_{x}\right)$ $\mathrm{MnO}_{3}$, respectively. Our results confirm that the dimensionality as well as ionic size plays an important role in controlling the colossal magnetoresistance in manganites. (C) 2001 Elsevier Science B.V. All rights reserved.
\end{abstract}

Keywords: Magnetic structure; XRD; TEM; Magnetometer

\section{Introduction}

Since the discovery of high-temperature superconductivity in perovskite copper oxides, there has been revived interest in mixed valence transition metal oxides. The $\mathrm{ABO}_{3}$-type manganites $\mathrm{R}_{n+1} \mathrm{Mn}_{n} \mathrm{O}_{3 n+1}(\mathrm{R}=$ rare earth and $n=\infty$ ), exhibit colossal magnetoresistance (CMR) in a relatively small temperature range around the Curie temperature $\left(T_{\mathrm{C}}\right)$ [1]. CMR is the large decrease in resistance under an applied magnetic field, concomitant with a paramagnetic insulator-like phase at high temperature and a ferromagnetic metallic phase at low temperature. Suitable substitution of $\mathrm{A}^{2+}$ ions for $\mathrm{R}^{3+}$ ions results in $\mathrm{Mn}^{3+} / \mathrm{Mn}^{4+}$ mixed valence, and hence the strong coupling between the magnetic ordering and the electrical conductivity leading to a strong relationship between the electrical resistivity and the spin alignment, which has been explained by the double-exchange mechanism [2]. This mechanism describes the transfer of an electron between the $\mathrm{Mn}^{3+}$ and $\mathrm{Mn}^{4+}$ ions. The electrons in the $e_{\mathrm{g}}$ orbitals of $\mathrm{Mn}^{3+}\left(t_{2 \mathrm{~g}}{ }^{3} e_{\mathrm{g}}{ }^{1}\right)$ ions are the charge carriers that move in a background of $\mathrm{Mn}^{4+}$ $\left(t_{2 \mathrm{~g}}{ }^{3}\right)$ ions. The alignment of the $\mathrm{Mn}^{4+}$ localized spins fa-

\footnotetext{
* Corresponding author. Tel.: +886-2-2369-0152; fax: +886-2-2363-6359.

E-mail address: rsliu@ccms.ntu.edu.tw (R.-S. Liu).
}

vors the delocalization of the $e_{\mathrm{g}}$ electrons and reduces the total energy of the system.

In the Ruddlesden-Popper (RP) $\mathrm{La}_{n-n x}(\mathrm{Sr}, \mathrm{Ca})_{1+n x} \mathrm{Mn}_{n^{-}}$ $\mathrm{O}_{3 n+1}$ system, the dimensionality can be varied by increasing the number of perovskite layers and by controlling the arrangement of $\mathrm{MnO}_{6}$ octahedra. Many interesting studies have been carried out on the manganites of the series $\mathrm{La}_{n-n x} \mathrm{Sr}_{1+n x} \mathrm{Mn}_{n} \mathrm{O}_{3 n+1}$ with $x=0.4$ and $n=2$. $\mathrm{La}_{1.2} \mathrm{Sr}_{1.8} \mathrm{Mn}_{2} \mathrm{O}_{7}$ is a conducting ferromagnet with a $T_{\mathrm{C}}$ of $130 \mathrm{~K}$ and with a high MR value; this composition is a paramagnetic insulator above $T_{\mathrm{C}}[3,4]$. The $c=2$ member of the RP series exhibits conducting ferromagnetic behavior with a MR ratio $([\rho(0)-\rho(H) / \rho(0)])$ higher than that of the $n=3$ and $\infty$ members, where $\rho(0)$ is the resistivity in zero field and $\rho(H)$ is the resistivity under a field of $1.5 \mathrm{~T}$ [1]. This implies that a lower dimensionality is more favorable for CMR. However, the properties of the solid solution of $\mathrm{Sr}^{2+}$ and $\mathrm{Ca}^{2+}$ in $\mathrm{La}_{1.2}\left(\mathrm{Sr}_{1.8-x} \mathrm{Ca}_{x}\right) \mathrm{Mn}_{2} \mathrm{O}_{7}$ have not been systematically studied.

In the $n=\infty$ compounds, the gradual replacement of $\mathrm{Ca}^{2+}$ by $\mathrm{Sr}^{2+}$ in $\mathrm{La}_{0.75}\left(\mathrm{Ca}_{0.25-x} \mathrm{Sr}_{x}\right) \mathrm{MnO}_{3}$ results in an increase of $T_{\mathrm{C}}$ from $\sim 225 \mathrm{~K}(x=0)$ to $\sim 340 \mathrm{~K}(x=$ $0.25)$ [5]. The phase transformation from orthorhombic to rhombohedral has been observed in the $\mathrm{La}_{0.75}\left(\mathrm{Ca}_{0.25-x} \mathrm{Sr}_{x}\right)$ $\mathrm{MnO}_{3}$ system with fixed $\mathrm{Mn}$ valence, which is difficult to explain as the effect of increasing the Mn valence. There- 
fore, a detailed study on the phase transformation is very informative.

In this paper, we report the evolution of the structural, electrical and magnetic properties of $\mathrm{La}_{1.2}\left(\mathrm{Sr}_{1.8-x} \mathrm{Ca}_{x}\right)$ $\mathrm{Mn}_{2} \mathrm{O}_{7}(0 \leq x \leq 0.8)$ possessing the layered structure, and $\mathrm{La}_{0.6}\left(\mathrm{Sr}_{0.4-x} \mathrm{Ca}_{x}\right) \mathrm{MnO}_{3}(0 \leq x \leq 0.4)$ with the 3D structure, wherein isovalent chemical substitution of $\mathrm{Ca}$ into the Sr sites has been carried out.

\section{Experimental}

High purity powders of $\mathrm{La}_{2} \mathrm{O}_{3}, \mathrm{SrCO}_{3}, \mathrm{CaCO}_{3}$ and $\mathrm{MnO}_{2}$ were weighed in appropriate proportions to obtain the nominal compositions of $\mathrm{La}_{1.2}\left(\mathrm{Sr}_{1.8-x} \mathrm{Ca}_{x}\right) \mathrm{Mn}_{2} \mathrm{O}_{7}$ $(0 \leq x \leq 0.8)$ [6] and $\mathrm{La}_{0.6}\left(\mathrm{Sr}_{0.4-x} \mathrm{Ca}_{x}\right) \mathrm{MnO}_{3}(0 \leq x \leq$ 0.4). The former were calcined in air for $24 \mathrm{~h}$ at $1200^{\circ} \mathrm{C}$ and the latter for $24 \mathrm{~h}$ at $900^{\circ} \mathrm{C}$. Then, the samples were sintered in air at $1400-1500^{\circ} \mathrm{C}$ for $72 \mathrm{~h}$ with an intermediate grinding after every $24 \mathrm{~h}$. X-ray powder diffraction (XRD) measurements were carried out with a SCINTAG (X1) diffractometer $(\mathrm{Cu} \mathrm{K} \alpha$ radiation, $\lambda=1.5406 \AA)$ at $40 \mathrm{kV}$ and $30 \mathrm{~mA}$. The program GSAS [7] was used for the Rietveld refinement in order to obtain the structural parameters. High-resolution transmission electron microscopy (HRTEM) was carried out using a JEOL 4000EX electron microscope operating at $400 \mathrm{kV}$. Magnetization data were collected on a superconducting quantum interference device (SQUID) magnetometer (quantum design).

\section{Results and discussion}

In Fig. 1, we show the XRD patterns of the series $\mathrm{La}_{1.2}\left(\mathrm{Sr}_{1.8-x} \mathrm{Ca}_{x}\right) \mathrm{Mn}_{2} \mathrm{O}_{7}(0 \leq x \leq 0.8)$. All of the samples are of single phase. The samples can be indexed to the $\mathrm{Sr}_{3} \mathrm{Ti}_{2} \mathrm{O}_{7}$-type structure with a tetragonal unit cell (space group: $I 4 / \mathrm{mmm}$ ). Based on our XRD refinements, both lattice constants $(a$ and $c$ ) and cell volume $(V)$ decrease as the $\mathrm{Ca}$ content increases. The structural changes are simply due to a manifestation of the size effect between $\mathrm{Ca}^{2+}(1.18 \AA$ for $\mathrm{CN}$ (coordination number) =9) and $\mathrm{Sr}^{2+}(1.31 \AA$ for $\mathrm{CN}=9$ ) [4]. The bottom left portion of Fig. 2 shows the crystal structure of $\mathrm{La}_{1.2}\left(\mathrm{Sr}_{1.4} \mathrm{Ca}_{0.4}\right) \mathrm{Mn}_{2} \mathrm{O}_{7}$ which consists of double perovskite layers, each layer consisting of a two-dimensional network of $\mathrm{MnO}_{6}$ octahedra. The unit cell is shown with a solid line and the arrangement of $\mathrm{MnO}_{6}$ octahedra is shaded. This model is also supported by HRTEM observations. Fig. 2 shows the HRTEM image with the incident electron beam along the [1 10 ] direction. The corresponding selected area electron diffraction pattern is shown in the top left. The lattice image clearly shows layers with uniform spacing of about $10 \AA$, which corresponds to nearly half the $c$-axis unit length. There are no stacking faults as can be observed from this image, indicating a high homogeneity in this compound. The electron diffraction pattern can be indexed with respect to the $h+k+l=2 n$ reciprocal lattice sections of the tetragonal cell with $a=b \sim 3.9 \AA$ and $c \sim 20 \AA$.

The powder XRD patterns of the $\mathrm{La}_{0.6}\left(\mathrm{Sr}_{0.4-x} \mathrm{Ca}_{x}\right) \mathrm{MnO}_{3}$ $(0 \leq x \leq 0.4)$ samples are shown in Fig. 3(a). All the samples of this series are of single phase. For the samples with $x=0$ and 0.4 , all the peaks in each pattern can be indexed with a rhombohedral unit cell (space group: $R-3 c$ ) and orthorhombic (space group: Pbnm), respectively. As $x$ increases to 0.3 , some reflections merge together, which indicates that in the region $x<0.3$, the structure is rhombohedral and for $x \geq 0.3$, the structure becomes orthorhombic. An increase in the $\mathrm{Ca}$ content in $\mathrm{La}_{0.6}\left(\mathrm{Sr}_{0.4-x} \mathrm{Ca}_{x}\right) \mathrm{MnO}_{3}$ leads to an increase in the distortion of the $\mathrm{MnO}_{6}$ octa-

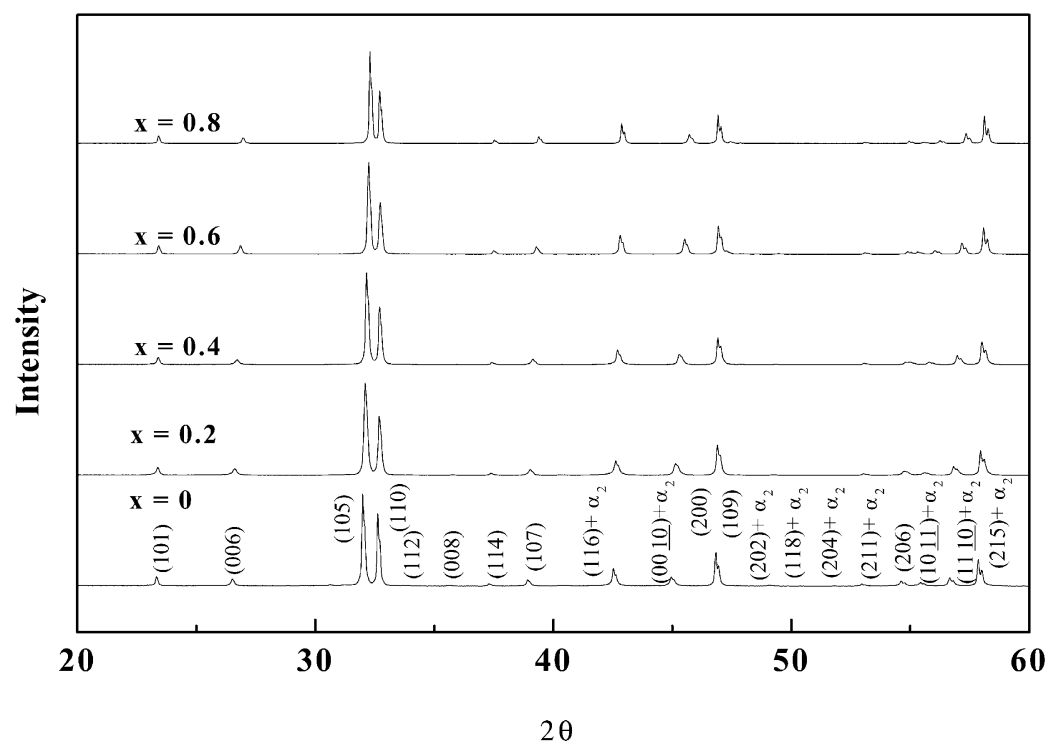

Fig. 1. Powder XRD patterns of the $\mathrm{La}_{1.2}\left(\mathrm{Sr}_{1.8-x} \mathrm{Ca}_{x}\right) \mathrm{Mn}_{2} \mathrm{O}_{7}$ samples. 


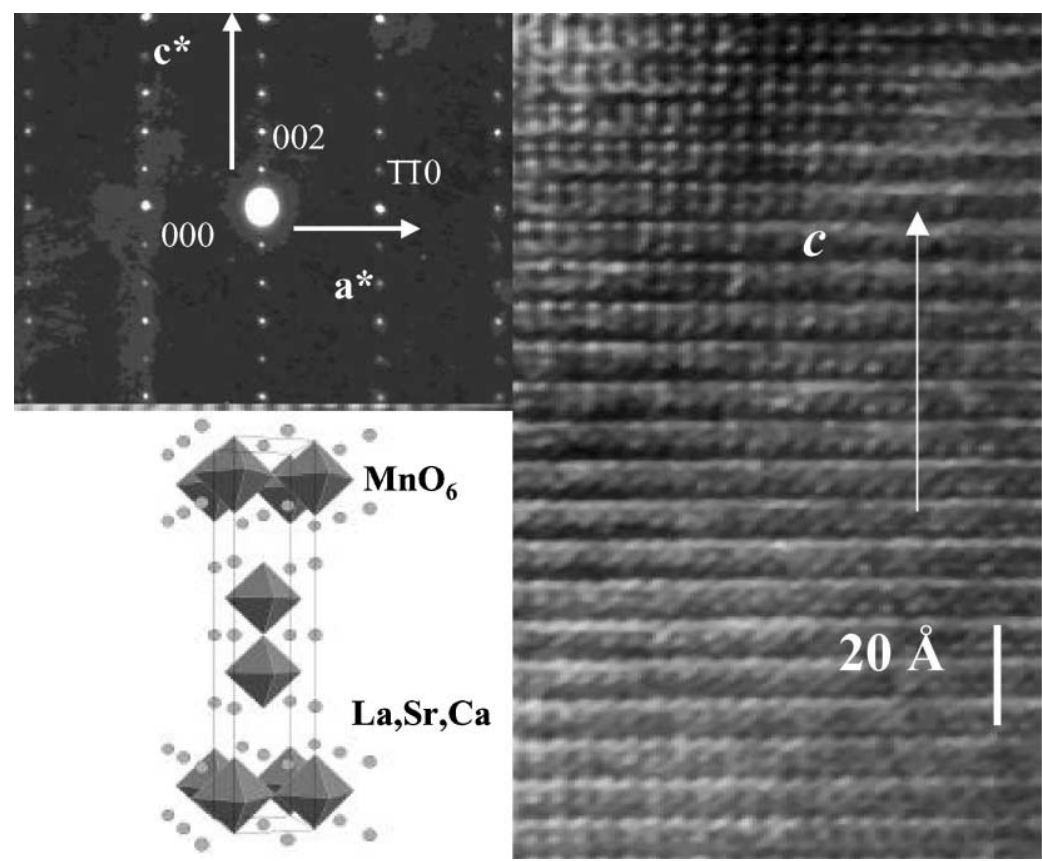

Fig. 2. HRTEM image along the $c$-axis for $\mathrm{La}_{1.2}\left(\mathrm{Sr}_{1.4} \mathrm{Ca}_{0.4}\right) \mathrm{Mn}_{2} \mathrm{O}_{7}$. The top left portion shows the electron diffraction pattern along [1 10$]$ of the tetragonal cell.
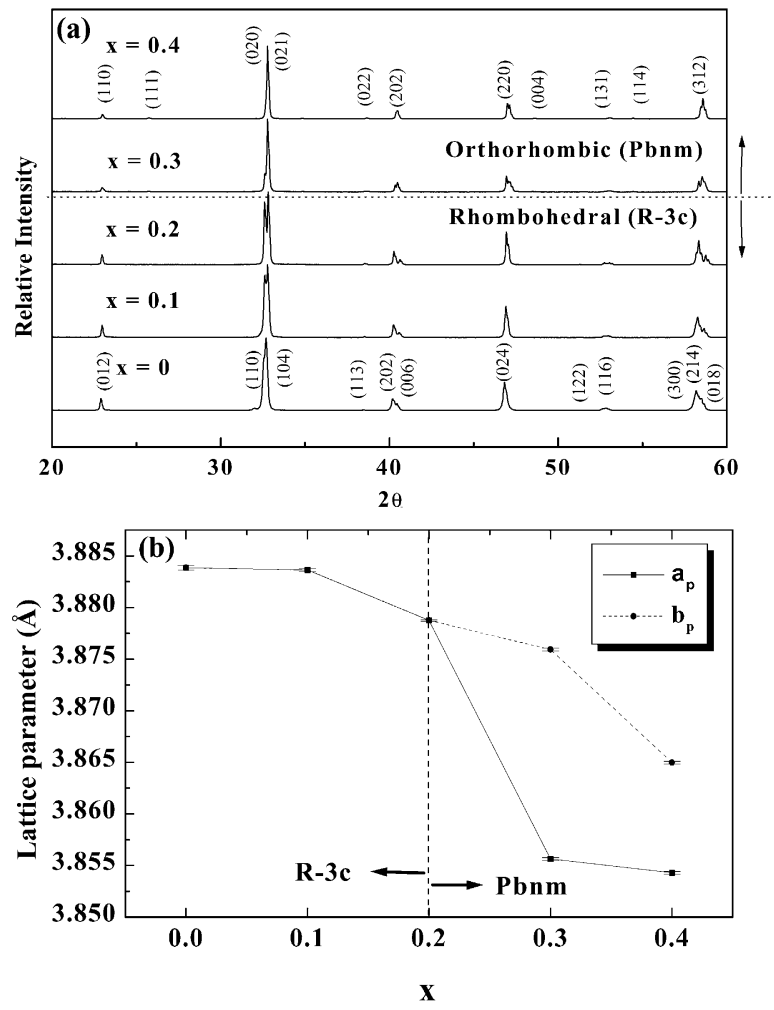

Fig. 3. (a) XRD patterns of the series $\mathrm{La}_{0.6}\left(\mathrm{Sr}_{0.4-x} \mathrm{Ca}_{x}\right) \mathrm{MnO}_{3}$. (b) Basic perovskite cell parameters $\left(a_{\mathrm{p}}\right.$ and $\left.b_{\mathrm{p}}\right)$ as a function of $x$ in $\mathrm{La}_{0.6}\left(\mathrm{Sr}_{0.4-x} \mathrm{Ca}_{x}\right) \mathrm{MnO}_{3}$. hedra. The basic perovskite lattice constants $\left(a_{\mathrm{p}}\right.$ and $\left.b_{\mathrm{p}}\right)$ also decrease as $x$ increases (as shown in Fig. 3(b)).

The crystal structure and the results of HRTEM of $\mathrm{La}_{0.6}\left(\mathrm{Sr}_{0.4-x} \mathrm{Ca}_{x}\right) \mathrm{MnO}_{3}$ are shown in Fig. 4. The HRTEM lattice image along [1 11] zone-axis direction of $\mathrm{La}_{0.6}\left(\mathrm{Sr}_{0.4-x} \mathrm{Ca}_{x}\right) \mathrm{MnO}_{3}(x=0.1)$ is shown in Fig. 4(a). The inset of Fig. 4(a) shows the structural model along [1 111 ] of the rhombohedral cell (space group: $R-3 c$ ) of $\mathrm{La}_{0.6}\left(\mathrm{Sr}_{0.4-x} \mathrm{Ca}_{x}\right) \mathrm{MnO}_{3}$. The corresponding lattice image is in agreement with the model. Fig. 4(b) shows the HRTEM lattice image along the [010] zone-axis direction of $\mathrm{La}_{0.6}\left(\mathrm{Sr}_{0.4-x} \mathrm{Ca}_{x}\right) \mathrm{MnO}_{3}(x=0.3)$. The structural model along [0 10 ] Pbnm) is shown in the inset of Fig. 4(b). The perfect order along the $c$-axis is confirmed by the HRTEM image. No superstructures were found in the $\mathrm{La}_{0.6}\left(\mathrm{Sr}_{0.4-x} \mathrm{Ca}_{x}\right) \mathrm{MnO}_{3}$ $(0 \leq x \leq 0.4)$ series samples.

The temperature dependence of the magnetization in an applied field of $0.1 \mathrm{~T}$ for $\mathrm{La}_{1.2}\left(\mathrm{Sr}_{1.8-x} \mathrm{Ca}_{x}\right) \mathrm{Mn}_{2} \mathrm{O}_{7}(0 \leq x \leq$ $0.8)$ and $\mathrm{La}_{0.6}\left(\mathrm{Sr}_{0.4-x} \mathrm{Ca}_{x}\right) \mathrm{MnO}_{3}(0 \leq x \leq 0.4)$ is shown in Fig. 5(a) and (b), respectively. A systematic analysis of the phase diagram of the transition temperature $\left(T_{\mathrm{C}}\right)$ versus the concentration of $\mathrm{Ca}^{2+}$ for $\mathrm{La}_{1.2}\left(\mathrm{Sr}_{1.8-x} \mathrm{Ca}_{x}\right) \mathrm{Mn}_{2} \mathrm{O}_{7}$ indicates that the $T_{\mathrm{C}}$ decreases from 135 to $71 \mathrm{~K}$ for $x=0-0.8$. For the series $\mathrm{La}_{0.6}\left(\mathrm{Sr}_{0.4-x} \mathrm{Ca}_{x}\right) \mathrm{MnO}_{3}$, paramagnetic to ferromagnetic transitions are observed in the temperature range of $250-350 \mathrm{~K}$, as can be seen from Fig. 5(b). A decrease in the $T_{\mathrm{C}}$ 's from a value greater than $350 \mathrm{~K}$ for $x=0$ to $270 \mathrm{~K}$ for $x=0.4$ has been observed. These results lead to the understanding that the $T_{\mathrm{C}}$ is very sensitive 

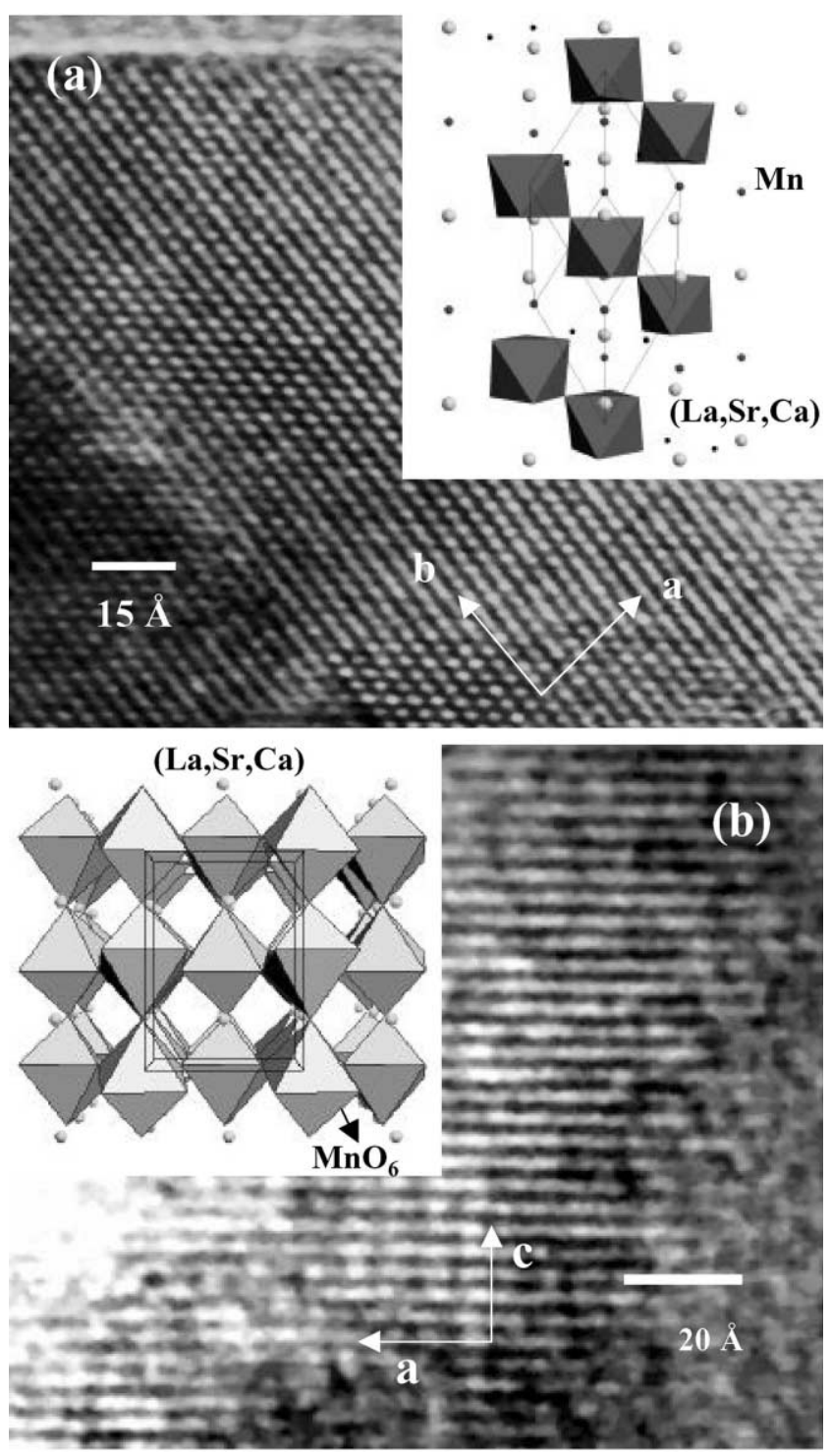

Fig. 4. HRTEM lattice images taken along the (a) [0 011$]$ zone-axis directions of the $\mathrm{La}_{0.6}\left(\mathrm{Sr}_{0.4-x} \mathrm{Ca}_{x}\right) \mathrm{MnO}_{3}$ sample with $x=0.1$. The corresponding rhombohedral structure is shown in the inset of (a). (b) [0 1 0 ] zone-axis directions of the $\mathrm{La}_{0.6}\left(\mathrm{Sr}_{0.4-x} \mathrm{Ca}_{x}\right) \mathrm{MnO}_{3}$ sample with $x=0.3$. The corresponding orthorhombic is shown in the inset of (b).

to chemical pressure (i.e., structural distortions induced by changing the average radius of the cations). This suggests that the smaller $\mathrm{Ca}^{2+}$ ions substituting into the bigger $\mathrm{Sr}^{2+}$ sites leads to a decrease in $T_{\mathrm{C}}$. Based on the model of double exchange, a lower $T_{\mathrm{C}}$ corresponds to a poor overlap between $\mathrm{Mn} \mathrm{3d}$ and O2p orbitals resulting in a reduced bandwidth $(W)[8,9]$. With increasing Ca content, there is a decrease in the overlap between $\mathrm{Mn} 3 \mathrm{~d}_{z}{ }^{2}$ and $\mathrm{O} 2 \mathrm{p}_{z}$ which may result in a decrease in $T_{\mathrm{C}}$ 's. Therefore, the structural transformation of the $\mathrm{La}_{0.6}\left(\mathrm{Sr}_{0.4-x} \mathrm{Ca}_{x}\right) \mathrm{MnO}_{3}$ compositions from rhombohedral to orthorhombic by chemical substitution of isovalent $\mathrm{Ca}^{2+}$ for $\mathrm{Sr}^{2+}$ causes a decrease in
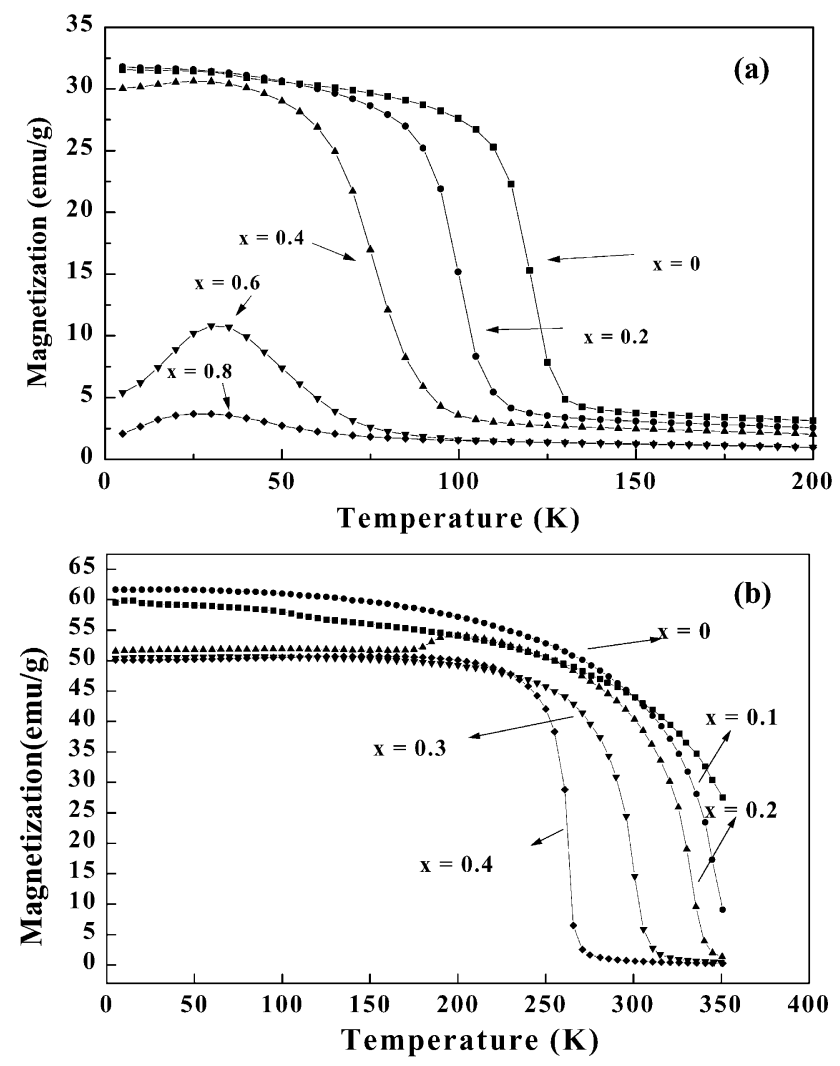

Fig. 5. Temperature dependence of magnetization at a magnetic field of $0.1 \mathrm{~T}$ for the series: (a) $\mathrm{La}_{1.2}\left(\mathrm{Sr}_{1.8-x} \mathrm{Ca}_{x}\right) \mathrm{Mn}_{2} \mathrm{O}_{7} \quad(x=0-0.8)$; (b) $\mathrm{La}_{0.6}\left(\mathrm{Sr}_{0.4-x} \mathrm{Ca}_{x}\right) \mathrm{MnO}_{3}(x=0-0.4)$.

$T_{\mathrm{C}}$ due to poor hybridization between $\mathrm{Mn} 3 \mathrm{~d}_{z}{ }^{2}$ and $\mathrm{O} 2 \mathrm{p}_{z}$ in the orthorhombic cell. The results are consistent with the series $\mathrm{La}_{0.6}\left(\mathrm{Sr}_{0.4-x} \mathrm{Ca}_{x}\right) \mathrm{MnO}_{3}$ with $x \geq 0.3$ exhibiting a distorted $\mathrm{MnO}_{6}$ octahedral structure which indicates that the Jahn-Teller distortion occurs along the $c$-axis in these

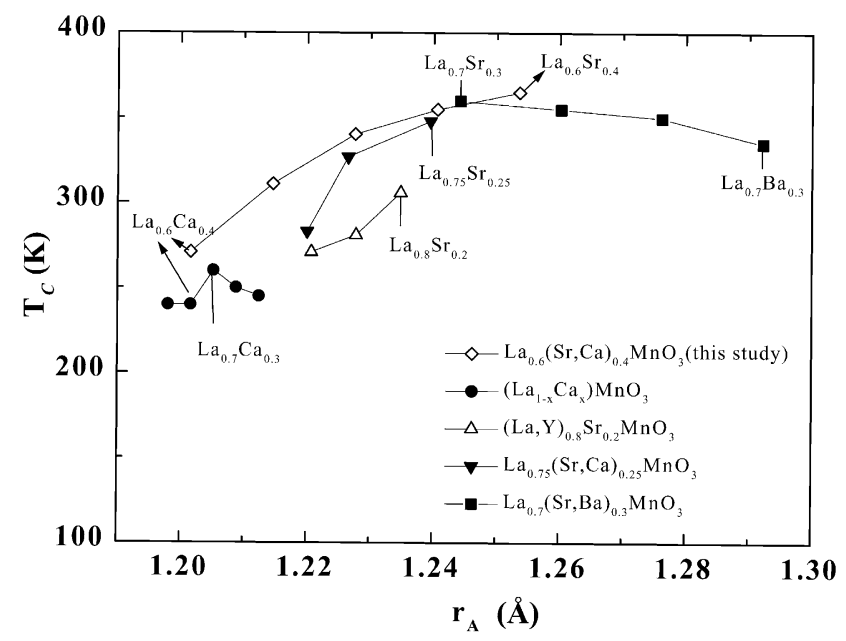

Fig. 6. Variation of $T_{\mathrm{C}}$ of $(\mathrm{Ln}, \mathrm{A}) \mathrm{MnO}_{3}$ as a function of the average radius $\left\langle r_{\mathrm{A}}\right\rangle$ of the $\mathrm{Ln} / \mathrm{A}(\mathrm{Ln}=\mathrm{La}$ or $\mathrm{Y} ; \mathrm{A}=\mathrm{Ca}, \mathrm{Sr}$ or $\mathrm{Ba})$ cations. 
compounds. Such an effect would lead to a decrease in the spatial overlap of the $\mathrm{Mn} 3 \mathrm{~d}_{z}{ }^{2}$ and $\mathrm{O} 2 \mathrm{p}_{z}$ orbital.

In Fig. 6, we show the $T_{\mathrm{C}}$ 's of $(\mathrm{Ln}, \mathrm{A}) \mathrm{MnO}_{3}$ as a function of the average radius (assuming ninefold coordination) of the $\mathrm{Ln} / \mathrm{A}(\mathrm{Ln}=\mathrm{La}$ or $\mathrm{Y} ; \mathrm{A}=\mathrm{Ca}, \mathrm{Sr}$ or $\mathrm{Ba})$ cations, $\left\langle r_{\mathrm{A}}\right\rangle=\left[(1-x) r_{\mathrm{Ln}}+x r_{\mathrm{A}}\right]$. The data in this figure include results from our study on the series $\mathrm{La}_{0.6}\left(\mathrm{Sr}_{0.4-x} \mathrm{Ca}_{x}\right) \mathrm{MnO}_{3}$, as also those from earlier studies [5,9,10]. An increase in $\left\langle r_{\mathrm{A}}\right\rangle$ gives rise to an increase in $T_{\mathrm{C}}$. Therefore, the isovalent chemical substitution of the smaller $\mathrm{Ca}^{2+}$ ions into the bigger $\mathrm{Sr}^{2+}$ sites in the series $\mathrm{La}_{n-n x}(\mathrm{Sr}, \mathrm{Ca})_{1+n x} \mathrm{Mn}_{n} \mathrm{O}_{3 n+1}$ causes the decrease of the $T_{\mathrm{C}}$ 's.

\section{Conclusion}

In conclusion, an investigation of the new series of two-dimensional $\mathrm{La}_{1.2}\left(\mathrm{Sr}_{1.8-x} \mathrm{Ca}_{x}\right) \mathrm{Mn}_{2} \mathrm{O}_{7}(0 \leq x \leq 0.8)$ and three-dimensional $\mathrm{La}_{0.6}\left(\mathrm{Sr}_{0.4-x} \mathrm{Ca}_{x}\right) \mathrm{MnO}_{3}(0 \leq x \leq$ $0.4)$ manganites has allowed us to establish the relationship between the ionic size and $T_{\mathrm{C}}$. This study has demonstrated that the size of the interpolated cation by tuning the concentration between $\mathrm{Ca}^{2+}$ and $\mathrm{Sr}^{2+}$ plays a crucial role in controlling the magnetotransport properties in the $\mathrm{La}_{n-n x}(\mathrm{Sr}, \mathrm{Ca})_{1+n x} \mathrm{Mn}_{n} \mathrm{O}_{3 n+1}$ compositions.

\section{Acknowledgements}

The work is supported by the National Science Council of the ROC under the grant numbers of NSC 89-2113-M002-004 and NSC 89-2112-M-002-030.

\section{References}

[1] R. Mahesh, R. Mahendiran, A.K. Raychaudhuri, C.N.R. Rao, J. Solid State Chem. 122 (1996) 448

[2] C. Zener, Phys. Rev. 82 (1951) 403.

[3] D.N. Argyriou, J.F. Mitchell, J.B. Goodenough, O. Chmaissem, S. Short, J.D. Jorgensen, Phys. Rev. Lett. 78 (1997) 1568.

[4] P.D. Battle, M.A. Green, N.S. Laskey, N. Jasmir, J.E. Millburn, L.E. Spring, S.P. Sullivan, M.J. Rosseinsky, J.F. Vente, J. Mater. Chem. 7 (1997) 977.

[5] Z.B. Guo, W. Yang, Y.T. Shen, Y.W. Du, Solid State Commun. 105 (1998) 89.

[6] C.-H. Shen, R.-S. Liu, S.-F. Hu, J.G. Lin, C.-Y. Huang, H.S. Sheu, J. Appl. Phys. 86 (1999) 2178.

[7] A.C. Larson, R.B. von Dreele, Generalized Structure Analysis System, Los Alamos National Laboratory, Los Alamos, NM, 1994.

[8] J.L. Garcia-Munoz, J. Fontcuberta, M. Suaaidi, X. Obradors, J. Phys. Condens. Matter 8 (1996) L787.

[9] P.G. Radaelli, G. Iannone, M. Marezio, H.Y. Huang, S.-W. Cheong, J.D. Jorgensen, D.N. Argyriou, Phys. Rev. B 56 (1997) 8265.

[10] H.Y. Hwang, S.-W. Cheong, P.G. Radaelli, M. Marezio, B. Batlogg, Phys. Rev. Lett. 75 (1995) 914. 